\title{
Practical validation of efficacy of the standardized ileal digestible amino acid values in diet formulation for broiler chickens
}

\author{
W. Szczurek ${ }^{1}$ \\ National Research Institute of Animal Production, \\ Department of Animal Nutrition and Feed Science \\ 32-083 Balice, Poland
}

(Received 23 July 2010; revised version 30 September 2010; accepted 26 November 2010)

\begin{abstract}
The aim of experiment was to determine the potential for the improvements in growth performance and carcass traits, and reduction of $\mathrm{N}$ excreta output in final rearing period of broiler chickens by formulating diets on standardized ileal digestible amino acid (SID AA) basis. The experimental diets were composed of wheat, faba beans, peas, maize DDGS, soyabean meal and one of the 3 rapeseed products: solvent-extracted meal (RSM), expeller-extracted cake (RSC) or full-fat seeds (FRS); control diet was based on maize and soyabean meal. Experimental diets were formulated in two versions, based on a total (T) or digestible (D) levels of Lys, Met, Cys, Thr and Trp in feed components: calculated with the use of the SID AA coefficients determined previously with 30-day-old birds. The control diet was formulated on total AA at the levels equivalent to the levels in the $\mathrm{T}$ subset of experimental diets. Irrespective of the rapeseed component type, formulating diets on a SID AA basis yielded improved performance and post-slaughter parameters, and reduced excreta $\mathrm{N}$ output compared with their total AA counterparts. These benefits were most pronounced in chickens fed on diet containing RSM. Feeding the T version of experimental diets had a significant adverse impact on chicken growth and slaughter performances, and resulted in higher $\mathrm{N}$ outputs compared with the control group. Formulating experimental diets with SID AA (D version) allowed to obtain mean values of feed conversion ratio and performance indexes, carcass and breast meat yields, and both absolute and relative $\mathrm{N}$ excretions not significantly different from the control group. Relative to the control diet, balancing digestible AA contents partially compensated the negative effects of total AA formulation on body weight gains during the experiment.
\end{abstract}

KEY WORDS: chickens, amino acids, ileal digestibility, rapeseed products, feed formulation, performance

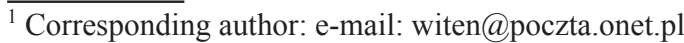




\section{INTRODUCTION}

The application of amino acid (AA) ileal digestibility data for operational formulation of broiler diets is of growing interest among nutritionists and feed manufacturers. Compared to total AA, the use of digestible AA system enables, among others, reduction of large safety margin of AA in feed formulations, which in turn may alleviate nitrogen-related pollution problem (Nahm, 2007). The methodology of determination of AA digestibility at the terminal section of the small intestine by sacrificing birds and sampling the ileal contents has undergone considerable development in recent years (Kadim et al., 2002; Kluth et al., 2005). This technique has now gained widespread acceptance as an approach for approximating the actual nutritional value of feed proteins for broiler chickens (Ravindran et al., 2005; Huang et al., 2007). Values of the apparent ileal digestibility (AID) for some important AA in different types of feedstuffs have been shown to increase with age of broilers (Huang et al., 2005; Adedokun et al., 2008). This implies that reliable ileal digestibility estimates for practical feed formulation should be assessed using birds with an age close to the given production phase. It is also clearly suggested that the AID coefficients should be corrected for defined basal endogenous losses of AA, which yields standardized ileal digestibility (SID) values (Hoehler et al., 2006; Adedokun et al., 2008). The SID coefficients of AA in various feed materials for chickens of different ages have been recently estimated and recommended by several laboratories (Bandegan et al., 2009; Szczurek, 2009; Woyengo et al., 2010). However, comprehensive parallel studies testing the practical utility of achieved values for more efficient feed formulation are scarce.

Much of the work currently undertaken at our laboratory is focused on determination the SID coefficients of AA for locally-grown crops and by-product materials in growing broilers (Szczurek, 2009, 2010). The present paper reports the results of performance and nitrogen balance trial conducted to compare the impact of dietary formulation based on total vs the SID AA values determined with broilers at the age of 30 days (Szczurek, 2009). The aim of the study was to evaluate whether multi-ingredient diets containing different rapeseed products and formulated with SID for five most important amino acids support performance and $\mathrm{N}$ output similar to the maize-soyabean meal control diet during last period of rearing broiler chickens.

\section{MATERIAL AND METHODS}

\section{Animals}

All procedures relating to the use of live birds were approved by the Local Ethics Committee for Animal Experimentation. Four hundred and forty-eight 21-day-old 
Ross 308 broiler chickens (sex ratio 1:1) were used in the trial. The chickens were individually weighted, randomly allocated to seven dietary treatments and placed in wire-floor cages equipped for the quantitative collection of excreta. The average initial body weight of birds was $574 \pm 9 \mathrm{~g}$. Eight replicate cages of 8 chickens $\left(4{ }^{\lambda}\right.$ and 4 9) were assigned to each treatment group. From days 22 to 42 broilers were kept under constant light/dark schedule (18/6 h, respectively) at a temperature of $22^{\circ} \mathrm{C}$ and received feed and water for ad libitum consumption.

\section{Diets and feeding managament}

The mash feeds were prepared to be isoenergetic and isonitrogenous (Table 1). Three basal experimental diets were composed of wheat, soyabean meal (SBM), a fixed amount of faba beans, field peas and maize DDGS, and included one of the 3 commercial double-low winter rapeseed products: solvent-extracted meal (RSM), with desolventizing-toasting as a final stage of meal processing, expeller cake from flaked/conditioned seeds (RSC) or grinded full-fat seeds (FRS). The dietary inclusion levels of these products were chosen to provide similar amounts of total lysine $(2.2 \mathrm{~g} / \mathrm{kg}$ of diet). The chemical composition, including contents of AA, and the standardized ileal AA digestibility values of all ingredients were determined in a previous study with 30-day-old broilers (Szczurek, 2009). The experimental diets were formulated in two versions of balancing Lys, Met, Cys, Thr and Trp contents, based on a total (T) or digestible (D) concentrations of these AA in feed components. Additionally, control maize-SBM diet was formulated to have total AA levels equivalent to the levels in the T subset of experimental diets. Feed formulations were based on total Lys $(0.89 \mathrm{~g})$ or SID Lys $(0.79 \mathrm{~g})$ in relation to $1 \mathrm{MJ}$ of metabolizable energy content. The ratios between Lys, Met, Cys, Thr and Trp were 100:45:31:65:17, respectively. These reference data were computed from published recommendations regarding total and SID AA dietary levels for broilers in a given production stage (Smulikowska and Rutkowski, 2005; Hoehler et al., 2006). All the diets were adequately supplemented with crystalline L-Lys, DL-Met and L-Thr considered as 100\% digestible. To match the above schedule, experimental diets, especially in D version, required to be supplemented with much higher levels of L-Thr than the control diet based on SBM. This was due to the considerably higher digestibility and content ('as fed' basis) of threonine in SBM than in the other protein-rich feeds used (Szczurek, 2009).

Body weight and feed intake were measured from day 22 to 42 on a replicate basis. The birds were observed twice daily, and mortality was recorded immediately upon observation. Mean weight gain (BWG), feed intake (FI) and feed conversion ratio (FCR), corrected for mortality, were calculated and used to determine the growth performance. Additionally, the efficiency of performance indexes (EPI) 
Table 1. Ingredients and nutrient composition $(\mathrm{g} / \mathrm{kg})$ of the control and experimental diets differing in rapeseed component and formulated on a total (T) or ileal digestible (D) amino acid basis

\begin{tabular}{|c|c|c|c|c|c|c|c|}
\hline \multirow{3}{*}{ Item } & \multicolumn{7}{|c|}{ Dietary treatment } \\
\hline & \multirow{2}{*}{ control - } & \multicolumn{2}{|c|}{$\mathrm{RSM}^{1}$} & \multicolumn{2}{|c|}{$\mathrm{RSC}^{1}$} & \multicolumn{2}{|c|}{$\mathrm{FRS}^{1}$} \\
\hline & & $\mathrm{T}$ & D & $\mathrm{T}$ & D & $\mathrm{T}$ & $\mathrm{D}$ \\
\hline \multicolumn{8}{|l|}{$\overline{\text { Feed ingredients }}$} \\
\hline RSM & & 120.00 & 120.00 & & & & \\
\hline $\mathrm{RSC}$ & & & & 120.00 & 120.00 & & \\
\hline FRS & & & & & & 195.00 & 195.00 \\
\hline maize & 571.20 & & & & & & \\
\hline wheat & & 440.19 & 438.35 & 455.54 & 454.46 & 432.82 & 431.79 \\
\hline constant components $^{2}$ & & 200.00 & 200.00 & 200.00 & 200.00 & 200.00 & 200.00 \\
\hline soyabean meal & 323.00 & 100.00 & 100.00 & 96.00 & 96.00 & 110.00 & 110.00 \\
\hline rapeseed oil & 62.00 & 96.50 & 97.20 & 85.00 & 85.00 & 19.00 & 19.00 \\
\hline $\mathrm{CaHPO}_{4}$ & 22.30 & 19.20 & 19.20 & 19.70 & 19.70 & 18.70 & 18.70 \\
\hline limestone & 8.10 & 8.90 & 8.90 & 8.60 & 8.60 & 9.60 & 9.60 \\
\hline $\mathrm{NaCl}$ & 3.00 & 3.00 & 3.00 & 3.00 & 3.00 & 3.00 & 3.00 \\
\hline premix $^{3}$ & 5.00 & 5.00 & 5.00 & 5.00 & 5.00 & 5.00 & 5.00 \\
\hline L-LysHCl 79\% & 1.90 & 3.84 & 4.11 & 3.91 & 4.08 & 3.54 & 3.76 \\
\hline DL-Met 99\% & 3.37 & 2.92 & 3.01 & 2.69 & 2.81 & 2.89 & 2.95 \\
\hline L-Thr 98\% & 0.13 & 0.45 & 1.23 & 0.56 & 1.35 & 0.45 & 1.20 \\
\hline \multicolumn{8}{|l|}{ Calculated $^{4}$} \\
\hline $\mathrm{ME}, \mathrm{MJ} / \mathrm{kg}$ & 13.0 & 13.0 & 13.0 & 13.0 & 13.0 & 13.0 & 13.0 \\
\hline crude protein ${ }^{5}$ & 186.3 & 186.4 & 186.2 & 186.3 & 186.2 & 186.5 & 186.4 \\
\hline crude fibre & 32.1 & 51.6 & 51.7 & 53.2 & 53.1 & 64.1 & 64.0 \\
\hline $\mathrm{Ca}$ & 8.9 & 8.9 & 8.9 & 8.9 & 8.9 & 8.9 & 8.9 \\
\hline $\mathrm{P}$ available & 4.4 & 4.4 & 4.4 & 4.4 & 4.4 & 4.4 & 4.4 \\
\hline $\begin{array}{l}\text { balanced amino acids } \\
\text { total }(T)\end{array}$ & & & & & & & \\
\hline lysine & 11.6 & 11.6 & 11.8 & 11.6 & 11.7 & 11.6 & 11.7 \\
\hline methionine & 5.2 & 5.2 & 5.2 & 5.2 & 5.2 & 5.2 & 5.2 \\
\hline methionine + cystine & 8.8 & 8.8 & 8.9 & 8.8 & 8.9 & 8.8 & 8.8 \\
\hline threonine & 7.5 & 7.5 & 8.2 & 7.5 & 8.3 & 7.5 & 8.2 \\
\hline tryptophan & 2.0 & 2.0 & 2.0 & 2.0 & 2.0 & 2.0 & 2.0 \\
\hline \multicolumn{8}{|l|}{ digestible $(D)$} \\
\hline lysine & 10.4 & 9.9 & 10.3 & 10.2 & 10.3 & 10.1 & 10.3 \\
\hline methionine & 4.8 & 4.4 & 4.6 & 4.5 & 4.6 & 4.6 & 4.6 \\
\hline methionine + cystine & 8.4 & 7.7 & 7.8 & 7.7 & 7.8 & 7.7 & 7.8 \\
\hline threonine & 6.3 & 5.9 & 6.7 & 5.9 & 6.7 & 5.8 & 6.7 \\
\hline tryptophan & 1.8 & 1.7 & 1.7 & 1.7 & 1.7 & 1.7 & 1.7 \\
\hline
\end{tabular}

${ }^{1}$ RSM - rapeseed meal, RSC - rapeseed cake, FRS - full-fat rape seeds; ${ }^{2}$ constant components - faba beans (50), field pea seeds (50), maize DDGS (100 g/ $\mathrm{kg}) ;{ }^{3}$ vitamin-trace mineral premix provided per kg of diet: IU: vit. A 12000, vit. D 2500; mg: vit. E 40, vit. K 2.25, vit. $\mathrm{B}_{1} 2.0$, vit. $\mathrm{B}_{2} 7.25$, vit. $\mathrm{B}_{6} 4.25$, vit. $\mathrm{B}_{12} 0.03$, biotin 0.1 , folic acid 1.0 , nicotinic acid 40 , calcium panthotenate 12 , choline chloride 450, Fe 65, Zn 65, Mn 100, Cu 15, I 0.8, Se 0.25, Co 0.4, coccidiostat - semduramycin $25 ;{ }^{4}$ as a sum of analysed components of feed ingredients; energy value using equations derived from The European Table of Energy Values for Poultry Feedstuffs (1989). WPSA, Wageningen; $\mathrm{Ca}$ and $\mathrm{P}$ contents - from tables of feed composition; ${ }^{5}$ confirmed by analysis 
were calculated using the following formula:

$$
\mathrm{EPI}=[\mathrm{BWG}, \mathrm{kg} / \text { day } \times(100 \text {-mortality, \%) } / \mathrm{FCR}] \times 100 .
$$

On day 29, four replicate cages per dietary treatment were chosen, feed intake was measured, and excreta of birds within a replicate were collected daily for 4 consecutive days. The total nitrogen content of diet and excreta were determined using a Tecator Kjeltec Auto 1030 System, and values of $\mathrm{N}$ output were calculated. At the end of the trial, ten birds ( $5 \widehat{O}$ and 5 P ) were selected from each treatment group and used for slaughter analysis.

\section{Statistical analysis}

The experimental design comprised two factors: type of rapeseed product included in the diet, and feed formulation based either on total or on SID amino acids. For growth performance $(n=8)$ and $N$ output $(n=4)$ parameters, cage means served as the experimental unit. Individual birds of both sexes $(n=10)$ were considered as the experimental unit for statistical analysis of post-slaughter data. The Levene's test provided evidence against equality of variances between the treatment groups. All data were subjected to analysis of variance (MANOVA) generated by Statistica ${ }^{\circledR}$ ver. 6 (StatSoft, 2001), and the main factor effects were separated by Tukey's HSD procedure. The statistical model was as follows:

$$
\mathrm{Y}_{\mathrm{ijk}}=\mathrm{m}+\mathrm{a}_{\mathrm{i}}+\mathrm{d}_{\mathrm{j}}+(\mathrm{ad})_{\mathrm{ij}}+\mathrm{e}_{\mathrm{ijk}}
$$

where: $Y_{i j k}$ - dependent variable, $m$ - overall mean, $a_{i}$ - effect of dietary formulation method, $\mathrm{d}_{\mathrm{j}}$ - effect of dietary rapeseed component, $(\mathrm{ad})_{\mathrm{ij}}$ - interaction between formulation method and dietary rapeseed component, $\mathrm{e}_{\mathrm{ijk}}$ - residual error term. Orthogonal contrasts (linear) for some pre-planned comparisons were tested for significance.

\section{RESULTS AND DISCUSSION}

Mortality during the experiment was moderate to low and the deaths ( 2 or 1 bird per group) were not associated with any specific dietary treatment. In general, type of dietary rapeseed component significantly influenced weight gain, as it was better $(\mathrm{P}<0.01)$ for RSC-containing diets than for the RSM- and FRS-containing ones, and both the feed conversion and EPI data showed similar effect (Table 2). The lower growth performance on FRS diets might have resulted from incomplete energy use from full-fat seeds, most probably due to the insufficient disruption of the oil-containing cells during the grinding process (Meng et al., 2006). On the other hand, the reason for impaired BWG and, thus, poorer FCR in birds fed 
Table 2. Growth performance during 22-42 days of life, post-slaughter indices, and absolute (g) and relative $(\%)$ nitrogen output

\begin{tabular}{|c|c|c|c|c|c|c|c|c|c|c|}
\hline \multirow{3}{*}{$\begin{array}{l}\text { Group } \\
\text { dietary treatment }{ }^{1}\end{array}$} & \multicolumn{10}{|c|}{ Parameter $^{2}$} \\
\hline & \multirow{3}{*}{$\begin{array}{c}\text { BWG } \\
\text { g }\end{array}$} & \multirow{2}{*}{$\begin{array}{l}\text { FI g/ } \\
\text { bird }\end{array}$} & \multirow{2}{*}{$\begin{array}{c}\text { FCR } \\
\mathrm{g} / \mathrm{g}\end{array}$} & \multirow{2}{*}{$\begin{array}{c}\text { MOR } \\
\%\end{array}$} & \multirow{2}{*}{$\begin{array}{c}\text { EPI } \\
\text { points }\end{array}$} & \multirow{2}{*}{$\begin{array}{c}\text { CY } \\
\%\end{array}$} & \multirow{2}{*}{$\begin{array}{c}\text { BMY } \\
\%\end{array}$} & \multirow{2}{*}{$\begin{array}{c}\text { AFD } \\
\%\end{array}$} & \multicolumn{2}{|c|}{$\mathrm{N}$ excretion } \\
\hline & & & & & & & & & g/bird/ & $\begin{array}{c}\% \\
\text { intake }\end{array}$ \\
\hline Control & & 3701 & 1.99 & 3.13 & 431 & 75.1 & 24.7 & 1.95 & 1.49 & 37.8 \\
\hline RSM-T & 1629 & 3458 & 2.12 & 3.13 & 354 & 73.2 & 22.1 & 3.02 & 1.80 & 43.6 \\
\hline RSM-D & 1736 & 3502 & 2.02 & 1.56 & 403 & 74.7 & 24.1 & 2.38 & 1.51 & 39.8 \\
\hline RSC-T & 1728 & 3545 & 2.06 & 1.56 & 394 & 74.1 & 23.0 & 2.72 & 1.88 & 42.3 \\
\hline RSC-D & 1790 & 3541 & 1.98 & 1.56 & 424 & 74.3 & 23.8 & 2.60 & 1.84 & 40.3 \\
\hline FRS-T & 1636 & 3438 & 2.11 & 3.13 & 361 & 74.0 & 22.8 & 2.81 & 1.66 & 41.4 \\
\hline FRS-D & 1710 & 3536 & 2.06 & 3.13 & 389 & 74.7 & 24.4 & 2.34 & 1.42 & 38.3 \\
\hline Pooled SEM & 13 & 19 & 0.01 & 0.67 & 6 & 0.14 & 0.18 & 0.07 & 0.04 & 0.54 \\
\hline \multicolumn{11}{|l|}{$\begin{array}{l}\text { Main effect means } \\
\text { rapeseed component }\end{array}$} \\
\hline RSM & $1683^{\mathrm{A}}$ & 3480 & $2.07^{\mathrm{a}}$ & 2.34 & $379^{\mathrm{a}}$ & 74.0 & 23.1 & 2.70 & $1.66^{\mathrm{a}}$ & 41.7 \\
\hline $\mathrm{RSC}$ & $1759^{\mathrm{B}}$ & 3543 & $2.02^{\mathrm{b}}$ & 1.56 & $409^{b}$ & 74.2 & 23.4 & 2.66 & $1.86^{\mathrm{b}}$ & 41.3 \\
\hline FRS & $1673^{\mathrm{A}}$ & 3487 & $2.08^{\mathrm{a}}$ & 3.13 & $375^{\mathrm{a}}$ & 74.3 & 23.6 & 2.58 & $1.54^{\mathrm{a}}$ & 39.9 \\
\hline \multicolumn{11}{|c|}{ formulation method } \\
\hline $\mathrm{T}$ & $1664^{\mathrm{A}}$ & 3481 & $2.10^{\mathrm{a}}$ & 2.60 & $370^{\mathrm{a}}$ & $73.7^{\mathrm{a}}$ & $22.6^{\mathrm{A}}$ & $2.86^{\mathrm{A}}$ & $1.78^{\mathrm{A}}$ & $42.4^{\mathrm{a}}$ \\
\hline $\mathrm{D}$ & $1745^{\mathrm{B}}$ & 3526 & $2.02^{\mathrm{b}}$ & 2.08 & $405^{\mathrm{b}}$ & $74.6^{\mathrm{b}}$ & $24.1^{\mathrm{B}}$ & $2.44^{\mathrm{B}}$ & $1.59^{\mathrm{B}}$ & $39.5^{\mathrm{b}}$ \\
\hline \multicolumn{11}{|l|}{ Significance of contrasts ${ }^{3}$} \\
\hline C1 (2 vs 3$)$ & ** & ns & ** & ns & ** & ** & $* *$ & ** & ** & $*$ \\
\hline $\mathrm{C} 2$ (4 vs 5$)$ & ns & ns & * & ns & ns & ns & ns & ns & ns & ns \\
\hline C3 (6 vs 7$)$ & * & ns & * & ns & * & ns & ** & $*$ & ** & ns \\
\hline C4 (1 vs 2, 4 and 6) & ** & $* *$ & $* *$ & ns & $* *$ & $* *$ & $* *$ & $* *$ & $* *$ & $* *$ \\
\hline C5 ( 1 vs 3,5 and 7$)$ & ** & ** & ns & ns & ns & ns & ns & $*$ & ns & ns \\
\hline
\end{tabular}

${ }^{1}$ dietary treatment abbreviations see Table $1 ;{ }^{2}$ BWG - body weight gain, FI - feed intake, FCR feed to BWG ratio, MOR - mortality, EPI - efficiency of performance index, CY - carcass yield ( $\%$ of live body weight), BMY - breast muscle yield ( $\%$ of carcass weight), AFD - abdominal fat deposition ( $\%$ of carcass weight) ${ }^{3}$ figures in brackets are the group numbers, ns - $\mathrm{P}>0.05 ;{ }^{*}-\mathrm{P}<0.05$; $* *-\mathrm{P}<0.01$; For main effects, means in a column with different letters differ significantly at: ${ }^{\mathrm{a}, \mathrm{b}}-\mathrm{P} \leq 0.05$; $\mathrm{A}, \mathrm{B}-\mathrm{P} \leq 0.01$

RSM-containing diets could be attributed to the lower digestibility of Lys and such important AA as Ile, Val, His and Gly (by 2.8-4.5 percentage points) in meal RSM than in cake RSC (Szczurek, 2009). It is noteworthy that low protein value of solvent-extracted and toasted rapeseed meal, relative to the expeller-extracted cake from precooked seeds, has also been shown by Smulikowska et al. (1997) in the extensive research on rats and chickens. As in previous similar study with younger broilers (Szczurek, 2010), there were no statistically significant differences in carcass yield (CY), breast meat yield (BMY) and abdominal fat deposition (AFD) associated with the type of dietary rapeseed product. The increased feed intake during the balance period was the first and probably the main cause of higher $(\mathrm{P}<0.05)$ absolute $\mathrm{N}$ output (g per day) in birds receiving the $\mathrm{RSC}$ diets. 
The overall results of this trial indicated that, irrespective of the rapeseed component type, formulating experimental diets on a SID AA basis yielded improved production and post-slaughter parameters, and reduced excreta $\mathrm{N}$ output compared with their total AA counterparts (D vs T; Table 2). As anticipated, the benefits of applying this formulation system were most pronounced in chickens fed diet containing RSM (contrast C1), the product which revealed the lowest SID of Lys, Met and Cys, and some other indispensable AA compared to the remaining two rapeseed feeds (Szczurek, 2009). In contrast to the RSM diet, formulation of RSC-containing diet based on the SID AA values had no significant impact on chicken growth (BWG), carcass parameters (CY, BMY, AFD) and excretion of nitrogenous compounds via the droppings (contrast $\mathrm{C} 2$ ). These results are close to those of Hoehler et al. (2006) in broilers fed maize-based diets containing 6 or $12 \%$ of cottonseed meal and optimized with SID Lys, Met + Cys and Thr. The authors concluded that it is of particular importance to balance diets with digestible AA in order to prevent or minimize the loss in bird performance, when low digestible feed materials at high inclusion rates are used.

Feeding the experimental diets formulated on a total AA basis resulted in significantly worse BWG, FCR, EPI values and slaughter indices, and higher $\mathrm{N}$ outputs compared to the control diet (contrast $\mathrm{C} 4 ; \mathrm{P}<0.01$ ), even though the calculated dietary contents of AA being under balancing were exactly the same. It is thus most likely that these differences were due to the considerable gap in digestible AA levels between the control and $\mathrm{T}$ versions of experimental diets (Table 1). This confirms the high sensitivity of broilers to dietary concentrations of digestible AA for growth and efficient converting dietary protein into body proteins (Szczurek, 2010). It should be stressed that the control diet was based entirely on maize and SBM, the plant ingredients with the highest ileal digestibility of indispensable AA among cereals and protein-rich feeds, respectively, evaluated in broilers at the age of 30 days (Szczurek, 2009).

The favourable responses in birds on diets formulated according to the digestible AA contents allowed to obtain mean values of FCR and EPI, carcass and breast meat percentages, and both $\mathrm{N}$ excretion indices not significantly different from the control group (contrast C5). However, the experimental diets balanced in SID AA (D version) still yielded BWG lower than the control diet. The general poorer growth rate of chickens fed diets composed mainly from locally produced feeds, compared with those of the control group, was due to strongly reduced feed intake $(\mathrm{P}<0.01)$. It may be speculated that the depressed feed consumption seen for both versions of experimental diets (contrasts C4 and C5) was, in large part, due to the increased level of undigested dietary fibre. It is important to notice, however, that the negative effects of diets formulated according total AA level on BWG (-195 g per bird on average, relative to the control diet) were partially compensated (by 62-107 g) after balancing SID AA contents. 


\section{CONCLUSIONS}

In conclusion, the application of digestible AA system enables meeting the broilers'age-based requirements for AA available for tissue synthesis more precisely. The results presented herein demonstrate that formulation of multiingredient diets composed with locally produced ingredients, in it different rapeseed products, using the SID AA values of raw materials determined with chickens of the given age class is superior to the conventional feed formulation method. Moreover, balancing these diets based on SID AA, unlike total AA, may give more consistent growth and slaughter performances, that are closer to those obtained with standard diets based on maize and soyabean meal.

\section{REFERENCES}

Adedokun S.A., Adeola O., Parsons C.M., Lilburn M.S., Applegate T.J., 2008. Standardized ileal amino acid digestibility of plant feedstuffs in broiler chickens and turkey poults using a nitrogenfree or casein diet. Poultry Sci. 87, 2535-2548

Bandegan A., Guenter W., Hoehler D., Crow G.H., Nyachoti C.M., 2009. Standardized ileal amino acid digestibility in wheat distillers dried grains with solubles for broilers. Poultry Sci. 88, 25922599

Hoehler D., Lemme A., Ravindran V., Bryden W.L., Rostagno H.S., 2006. Feed formulation in broiler chickens based on standardized ileal amino acid digestibility. In: L.E. Cruz-Suarez, D. Ricque-Marie, M. Tapia-Salazar, M.G. Nieto-Lopez, D.A. Villarreal-Cavazos, A.C. PuelloCruz, A. Garcia-Ortega (Editors). Advances in Poultry Nutrition VIII. Simposium Internacional de Nutrición Acuícola. UANL, Monterrey, Nuevo León (Mexico), pp. 197-212

Huang K.H., Ravindran V., Li X., Bryden W.L., 2005. Influence of age on the apparent ileal amino acid digestibility of feed ingredient for broiler chickens. Brit. Poultry Sci. 46, 236-245

Huang K.H., Ravindran V., Li X., Ravindran G., Bryden W.L., 2007. Apparent ileal digestibility of amino acids in feed ingredients determined with broilers and layers. J. Sci. Food Agr. 87, 47-53

Kadim I.T., Moughan P.J., Ravindran V., 2002. Ileal amino acid digestibility assay for the growing meat chicken - comparison of ileal and excreta amino acid digestibility in the chicken. Brit. Poultry Sci. 43, 588-597

Kluth H., Mehlhorn K., Rodehutscord M., 2005. Studies on the intestine section to be sampled in broiler studies on precaecal amino acid digestibility. Arch. Anim. Nutr. 59, 271-279

Meng X., Slominski B.A., Campbell L.D., Guenter W., Jones O., 2006. The use of enzyme technology for improved energy utilization from full-fat oilseeds. Part I: canola seed. Poultry Sci. 85, 1025-1030

Nahm K.H., 2007. Feed formulations to reduce $\mathrm{N}$ excretion and ammonia emission from poultry manure. Bioresource Technol. 98, 2282-2300

Ravindran V., Hew L.I., Ravindran G., Bryden W.L., 2005. Apparent ileal digestibility of amino acids in dietary ingredients for broiler chickens. Anim. Sci. 81, 85-97

Smulikowska S., Pastuszewska B., Mieczkowska A., Ochtabińska A., 1997. Chemical composition, energy value for chickens, and protein utilization in rats of rapeseed expeller cakes produced by different pressing technologies. J. Anim. Feed Sci. 6, 109-121 
Smulikowska S., Rutkowski A. (Editors), 2005. Nutritional Recommendations and Feed Composition Tables for Poultry (in Polish). Publishers: The Kielanowski Institute of Animal Physiology and Nutrition, Polish Academy of Sciences, Jabłonna (Poland) and Polish Branch of WPSA, pp. 41-47

StatSoft, 2001. Statistica for Windows. Computer Program Manual. $6^{\text {th }}$ Edition. StatSoft Inc. Tulsa, OK Szczurek W., 2009. Standardized ileal digestibility of amino acids from several cereal grains and proteinrich feedstuffs in broiler chickens at the age of 30 days. J. Anim. Feed Sci. 18, 662-676

Szczurek W., 2010. Performance and nitrogen output in young broilers fed diets containing different plant by-products and formulated with predetermined ileal digestible amino acid values. Ann. Anim. Sci. 10 (3) ( in press)

Woyengo T.A., Kiarie E., Nyachoti C.M., 2010. Metabolizable energy and standardized ileal digestible amino acid contents of expeller-extracted canola meal fed to broiler chicks. Poultry Sci. $89,1182-1189$ 